\title{
CONTROLLED TRIAL OF METHENOLONE ACETATE IN PREDNISOLONE-TREATED RHEUMATOID ARTHRITIS PATIENTS
}

\author{
BY \\ H. F. WEST AND E. LEWIS-FANING \\ For the ARThritis AND Rheumatism COUNCIL FOR Research \\ London
}

Many derivatives of testosterone have been synthesized which in man promote weight gain and a positive nitrogen and calcium balance in doses that cause relatively little evidence of androgen action. In rats these preparations cause an increase in the weight of the levator ani muscle which is said to constitute a "myotrophic" effect. In theory such hormones might be expected to improve the state of severely-affected rheumatoid arthritic patients receiving long-term prednisolone therapy. The improvements that might occur would be:

(1) An improvement in deficient musculature that might be reflected in an improved functional capacity and increased strength of grip;

(2) A decreased incidence of, or reversal of, osteoporosis that could be looked for in lateral radiographs of the lumbar spine;

(3) A decrease in the atrophy of skin which is clinically manifest in "pathological bruising" of the limbs and senile type "purpura" of the forearms and hands.

If the "anabolic" hormone had any effect upon the disease process itself, this might be detectable in the erythrocyte sedimentation rate, the haemoglobin concentration, and the changes observed in radiographs of hands and feet. This report is of a double-blind trial of methenolone acetate (Primobolan) tablets (5 $\mathrm{mg}$. twice daily) versus dummy tablets, of identical presentation, lasting one year and conducted at a number of hospitals.*

* Departments for the treatment of rheumatic diseases in the following hospitals took part:

The London Hospital

Manchester Royal Infirmary

Nether Edge Hospital, Sheffield

Nothern General Hospital, Edinburgh

Royal National Hospital, Bath

Royal Victoria Hospital, Newcastle

West London Hospital

Westminster Hospital

Withington Hospital. Manchester
All patients were given calcium tablets. The results of a trial of this nature have not previously been reported.

\section{The Patients}

The criteria for admission to the trial were:

(1) The subjects were to be ambulant females only, of age 20 to 65 years, weighing less than $75 \mathrm{~kg}$.

(2) The duration of prednisolone or equivalent therapy was to have been at least 1 year at a mean dose of $7 \cdot 5$ to $12.5 \mathrm{mg}$./day.

(3) The patients should not be suffering from any disorder thought likely to interfere with the interpretation of the trial.

\section{Allocation}

Particulars of patients considered suitable for the trial were sent to the statistician (Dr. Lewis-Faning) who put them into four groups: pre-menopausal and postmenopausal with previous corticosteroid therapy of less than or more than 4 years. Within each group he allocated tablets " $x$ " or " $y$ " at random.

\section{Procedure}

Forms were provided for entry details, for records at weeks $0,8,16,24,32,40$, and 48 , and for a final summary and comment. Each form was sent, on completion, to the statistician. Radiographs of the hands, feet, and lateral lumbar spine were taken, and the sheep cell agglutination or latex-fixation tests performed, at the start and at the end of the trial year.

\section{Results}

The findings were analysed in detail by the statistician who alone knew which was the active tablet until the last patient had completed 1 year in the trial. Much of the detail proved to be noncontributory and will be omitted from the findings given below.

(1) Composition of the Groups. -84 patients started the trial but fifteen of these failed to complete the first period, leaving only 69 . Five control and two treated patients stopped because of side-effects of a 
similar nature. A futher three control and two treated patients failed to return. The fifteen patients were considered as false-starters and are not included in the calculations in Table $I$, which gives details of the forty treated patients and 29 controls. It will be seen that there was no marked difference between the groups in any characteristic. During the course of the year six treated and five control patients left the trial, leaving a final total of 58 ; in only one case had the exclusion or withdrawal been attributable to treatment and in this instance withdrawal had been due to increasing acne. A study of the trends of change in each characteristic of each group over the year did not reveal any significant effect resulting from the dropping out of these patients. Table II shows the number of patients assessed at each period.

(2) Prednisolone Therapy.-This was continued in all the patients throughout the year. The mean daily dosage of those who completed the year was as follows:

\begin{tabular}{rr|c|c|c}
\hline Group & First Period & Last Period & Mean for Year \\
\hline Methenolone &.. & 9 & $9 \cdot 3$ & $9 \cdot 1$ \\
Control $\quad$. &. & $8 \cdot 8$ & $8 \cdot 8$ & $8 \cdot 8$ \\
\hline
\end{tabular}

The lowest individual mean dose for the year was $7.0 \mathrm{mg}$. and only one patient had a mean daily dose above $12 \cdot 5 \mathrm{mg}$.
(3) Weight.-The only statistically significant change that occurred during the year within each group or between them was a mean rise of $1.36 \mathrm{~kg}$. in the treated group between weeks 0 and 8 . This mean increase was 4.8 times the standard error of the difference of the means and was an increase common to most of the treated patients. At the end of the trial the mean weight of the treated patients was still $1 \mathrm{~kg}$. above the starting weight in spite of attempts by a number of patients to diet. The mean weight of the controls at the end of the trial was $1 \mathrm{~kg}$. below their starting weight.

(4) Skin-fold Thickness. - An attempt was made to find out whether any increase in weight that might occur was due to increased fat deposition. This was done by estimating the thickness of subcutaneous fat with Verel calipers. Two sites were used, the middle third of the back of the left arm and just below the left scapula.

The arm measurement for the treated group fell from 1.57 to $1.25 \mathrm{~cm}$., whereas the control group fell only from 1.7 to $1.65 \mathrm{~cm}$. The end of year figures are significantly different.

The back measurements showed the reverse trend; the treated group measurement rose from 0.98 to $1 \cdot 18 \mathrm{~cm}$., whereas those for the control group fell from $1 \cdot 31$ to $1 \cdot 28 \mathrm{~cm}$.

A study of all the measurements made at each assessment period revealed some instances of changes

TABLE I

MEANS FOR SOME CHARACTERISTICS OF THE METHENOLONE-TREATED AND CONTROL GROUPS

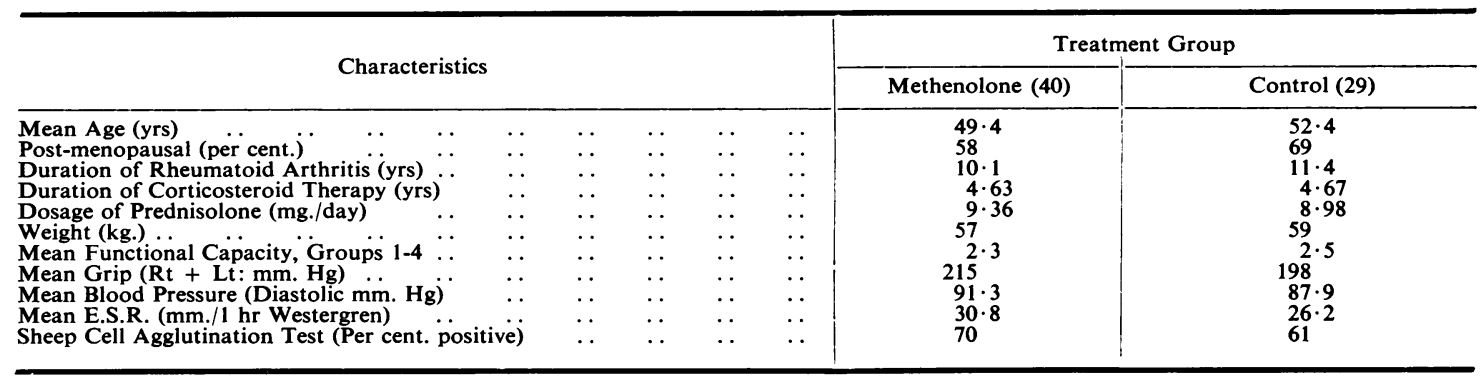

TABLE II

NUMBER OF PATIENTS ASSESSED AT EACH PERIOD

\begin{tabular}{|c|c|c|c|c|c|c|c|c|c|c|c|}
\hline \multirow{2}{*}{\multicolumn{5}{|c|}{ Treatment Group }} & \multicolumn{7}{|c|}{ Assessment Week } \\
\hline & & & & & $\mathbf{0}$ & 8 & 16 & 24 & 32 & 40 & 48 \\
\hline $\begin{array}{l}\text { Methenolone } \\
\text { Control } \quad \text {.. }\end{array}$ & $\begin{array}{l}\cdots \\
\cdots\end{array}$ & $\begin{array}{l}\cdots \\
\cdots\end{array}$ & $\begin{array}{l}\cdots \\
\cdots\end{array}$ & $\begin{array}{c}\cdots \\
\cdots\end{array}$ & $\begin{array}{l}40 \\
29\end{array}$ & $\begin{array}{l}40 \\
29\end{array}$ & $\begin{array}{l}39 \\
28\end{array}$ & $\begin{array}{l}38 \\
26\end{array}$ & $\begin{array}{l}38 \\
26\end{array}$ & $\begin{array}{l}34 \\
25\end{array}$ & $\begin{array}{l}34 \\
24\end{array}$ \\
\hline Total & . & $\ldots$ & . & $\ldots$ & 69 & 69 & 67 & 64 & 64 & 59 & 58 \\
\hline
\end{tabular}


in skin-fold thickness measurements without changes in body weight-suggesting that some measurements were not readily reproducible. In consequence we think that the finding of a more Cushingoid distribution of fat in the treated group should be taken as suggested but not proven.

(5) Strength of Grip.-The mean strength of grip of each group remained almost constant throughout the year.

(6) Blood Pressure.-There was no significant increase in the diastolic blood pressure of either group at the end of the year, but at Weeks 24 and 40 the diastolic blood pressure of the treated group was significantly higher than that of the controls. This was due to a rise from Week 0 to 24 in the treated group and a fall in the controls. The mean diastolic blood pressures of both groups were higher than one would expect of a similar group of patients not on long-term prednisolone therapy.

(7) Erythrocyte Sedimentation Rate (E.S.R.).-This was measured by the Westergren method (1 hr) for all patients except a balanced group of sixteen for whom the Wintrobe $(1 \mathrm{hr})$ method was used. The means at each assessment are shown in Table III. When these means and their standard deviations were compared, no statistical difference was found at any period, but this does not show that the early fall and the late rise in E.S.R. in the treated group could have occurred by chance-it only fails to provide evidence that it was unlikely to have occurred by chance. The reason for this is the very wide scatter in E.S.R. readings between one patient and another.

It may be, therefore, that therapy did cause a fall in E.S.R. in some patients and that the fall was only temporary.

(8) Haemoglobin Concentration.-Table III gives the mean haemoglobin concentrations recorded. From Week 24 there was a significant but small advantage to the treated group. At the start the mean of the treated group was 102 per cent. of that of the controls; it rose to a maximum of 112 per cent. at the 32nd week and had fallen back to 107 per cent by the 48 th week.

(9) Sheep Cell Agglutination and Latex-Fixation Tests.-There was no significant change in the number with positive tests in each group at the end of the year, nor was there a significant difference in the changes in titre.

\section{(10) Radiographs}

(A) Hands and Feet.-The radiographs of hands and feet were read, with knowledge of which had been taken at Week 0 and which at Week 48, both at the hospital of origin and by an independent reader. Nearly all the changes observed were small and many equivocal owing to some films not being exactly comparable. The readers agree that some deterioration was present in 22 per cent. of the hands and 13 per cent. of the feet of the treated group and in 29 per cent. of the hands and 10 per cent. of the feet of the control group. It is likely that these differences would have been less had the films been read "blind". The presence of new erosions was equally difficult to determine as so few were unequivocal. This is well shown in Table IV (opposite).

The mean number of new erosions recorded by the hospital readers per patient was 0.4 for the combined groups, and one patient accounted for 50 per cent of these. The independent reader found a mean of 0.33 per patient.

Neither in respect of deterioration of radiographic appearances nor in the incidence of new bone erosions was any significant difference found between the treated and control groups.

(B) Lumbar Spine.-The assessment of changes in bone density of the spine is notoriously difficult to assess unless the differences are gross. This is

\section{TABLE III}

MEAN ERYTHROCYTE SEDIMENTATION RATES AND MEAN HAEMOGLOBIN CONCENTRATIONS AT EACH ASSESSMENT The asterisk denotes a statistically significant difference

\begin{tabular}{|c|c|c|c|c|c|c|c|c|}
\hline \multirow{2}{*}{ Investigation } & \multirow{2}{*}{ Treatment Group } & \multicolumn{7}{|c|}{ Assessment Week } \\
\hline & & 0 & 8 & 16 & 24 & 32 & 40 & 48 \\
\hline $\begin{array}{l}\text { Erythrocyte Sedimentation Rate } \\
\text { (mm./1 hr) }\end{array}$ & $\begin{array}{l}\text { Methenolone } \\
\text { Control } \quad \text {. }\end{array}$ & $\begin{array}{l}30 \cdot 8 \\
26 \cdot 2\end{array}$ & $\begin{array}{l}26 \cdot 4 \\
28 \cdot 5\end{array}$ & $\begin{array}{l}22 \cdot 7 \\
26 \cdot 8\end{array}$ & $\begin{array}{l}25 \cdot 6 \\
26 \cdot 1\end{array}$ & $\begin{array}{l}24 \cdot 8 \\
25 \cdot 6\end{array}$ & $\begin{array}{l}28 \cdot 3 \\
20 \cdot 6\end{array}$ & $\begin{array}{l}32 \cdot 4 \\
25 \cdot 1\end{array}$ \\
\hline $\begin{array}{c}\text { Haemoglobin Concentration } \\
(\mathrm{g} . / 100 \mathrm{ml} .)\end{array}$ & $\begin{array}{l}\text { Methenolone } \\
\text { Control } \quad \text {. }\end{array}$ & $\begin{array}{l}12 \cdot 86 \\
12 \cdot 56\end{array}$ & $\begin{array}{l}12 \cdot 95 \\
12 \cdot 23\end{array}$ & $\begin{array}{l}12 \cdot 99 \\
12 \cdot 49\end{array}$ & $\begin{array}{l}13 \cdot 48 \\
12 \cdot 31^{*}\end{array}$ & $\begin{array}{l}13 \cdot 73 \\
12 \cdot 27^{*}\end{array}$ & $\begin{array}{l}13 \cdot 44 \\
12 \cdot 34^{*}\end{array}$ & $\begin{array}{l}13 \cdot 31 \\
12 \cdot 39\end{array}$ \\
\hline
\end{tabular}


TABLE IV

PERCENTAGE OF PATIENTS FOUND TO HAVE RADIOGRAPHIC EVIDENCE OF NEW BONE EROSIONS IN HANDS AND FEET

\begin{tabular}{|c|c|c|c|c|c|c|c|c|c|c|}
\hline Treatment Group & . & . & . & . & & Methenolone & & & Control & \\
\hline Reading & . & . & . & . & Hospital & Independent & Combined & Hospital & Independent & Combined \\
\hline Percentage & & Hands & & $\cdots$ & 3 & 12 & 16 & 26 & 17 & 39 \\
\hline New Erosions & & Feet & . & $\ldots$ & 6 & 0 & 6 & 4 & 0 & 4 \\
\hline
\end{tabular}

particularly true when a year elapses between the taking of the pictures as so often the radiographic techniques are not identical. The lateral films of the lumbar spine were read with knowledge of which had been taken at Week 0 and which at Week 48 . The hospital readers found one treated patient with less osteoporosis, one untreated patient with less and one with more. The independent reader found none with less osteoporosis, and two treated patients with more.

(C) Crush Fractures.-A partially-crushed vertebra was noted by both readers in three patients, all in the treated group:

One was found to be present before the trial and not to have changed during the trial.

One was found to have occurred during the trial.

The third occurred during the trial according to the hospital reader, but was considered only to have increased during the trial by the independent reader.

One can only conclude from these findings that there was no radiographic evidence to suggest that the methenolone therapy was beneficial.

(11) Analgesics.-The use of analgesics was recorded. Only two patients were noted as having none. The numbers and types of analgesics taken by each group were similar and remained practically constant throughout the year. The majority in each group took some form of aspirin three or four times a day.

(12) Clinical Assessments of "functional capacity" and pathological bruising.-Analysis of the records of the former showed that the percentage of improvement (actual of possible) and the percentage of deterioration (actual of possible) for the two groups did not differ significantly. Some evidence of pathological bruising was recorded for 80 per cent. of the patients. The impressions given of improvement and deterioration were the same for each group.

(13) Side-Effects. - The only side-effect that was peculiar to the treated group was acne, which was reported by four patients (10 per cent.). As physicians were not asked to state whether acne was present or not, it is likely that 10 per cent. is an under-estimate of the frequency of this side-effect.

\section{Discussion}

That the treated group did receive an "anabolic" hormone is apparent from the occurrence of acne and the significant weight increase. The apparent increase in back skin-fold thickness at the expense of arm skin-fold thickness may also reflect the action of an "anabolic" hormone.

The only statistically significant improvement noted was in the haemoglobin concentration of the treated group in the last 4 months.

These findings are disappointing so far as a hoped-for benefit from the anabolic hormone is concerned, but the documentation of objective assessments for a year in a defined group of rheumatoid arthritic patients receiving long-term prednisolone therapy is of interest and of value as a yardstick for other trials. One observation made is of particular interest, namely the small number of new bone erosions noted. This finding is in agreement with that of the Prednisolone/Analgesic Trial of the Joint Committee of the Medical Research Council and Nuffield Foundation (1959), and contrasts markedly with the evidence of bone erosion in patients not treated with prednisolone in that trial and in both the E.R.C.Cortisone/Aspirin Trial(1957) and the E.R.C. Gold Therapy Trial (1960). This finding may have a bearing on the mode of action of small doses of prednisolone, as was pointed out by West (1962).

\section{Summary}

A double-blind controlled trial was made of methenolone acetate, $5 \mathrm{mg}$. twice daily by mouth, in the treatment of female rheumatoid arthritic patients who were receiving long-term prednisolone therapy; 58 patients completed 1 year, 34 on methenolone and 24 controls. The two groups were well matched in respect of age, menopausal status, weight, skin-fold thickness, duration of rheumatoid arthritis, duration of prednisolone therapy, E.S.R., 
$\mathrm{Hb}$ concentration, S.C.A.T. or latex-fixation tests, strength of grip, and functional capacity. There was no evidence that the patients who left the trial significantly affected the comparability of the groups or the eventual findings. The only statistically significant differences found between the groups was an increase in weight in the first 8 weeks and a rise in haemoglobin concentration in the last 24 weeksboth in the treated group. The trends of change in skin-fold thickness suggested that the methenolonetreated group had an increase in fat deposition below the scapula and a decrease at the back of the arm. No significant difference was found in the radiographic changes observed in hands, feet, and lumbar spine. The only side-effect peculiar to the treated group was acne (in 10 per cent.).

Special thanks are due to Drs. Friebel and Hittel of Shering A.G. for providing the methenolone tablets and identical control tablets, suitably packed and in ample quantity.

\section{REFERENCES}

Empire Rheumatism Council (1957). Ann. rheum. Dis., 16, 277.

- (1960). Ibid., 19, 95.

Joint Committee of the Medical Research Council and Nuffield Foundation (1959). Ibid., 18, 173.

West, H. F. (1962). Lancet, 2, 590.

\section{Essai contrôlé de l'acétate de méthénolone chez des femmes atteintes d'arthrite rhumatismale et traitées par la prednisolone}

\section{RÉSUMÉ}

On a procédé à un essai contrôlé, double-blind, de l'acetate de méthénolone, $5 \mathrm{mg}$. par os deux fois par jour, dans le traitement des malades atteints d'arthrite rhumatismale et soumis à la thérapie prolongée par la prednisolone; 58 femmes ont complété une année de l'essai, 34 d'entre elles au régime de méthénolone et 24 comme témoins. Les deux groupes se ressemblaient en ce qui concerne l'âge, l'état ménopausique, le poids, l'épaisseur du pli cutané, la durée de l'arthrite rhumatismale, la durée de la thérapie à la prednisolone, la sédimentation globulaire, le taux de l'hémoglobine, la réaction de Waaler-Rose ou de fixation du latex, la force de la main et la capacité fonctionnelle. Rien n'indiquait que les malades qui avaient abandonné l'essai aient affecté appréciablement la comparabilité des groupes ou les résultats éventuels.

On n'a trouvé que deux différences statistiquement significatives entre ces deux groupes: une augmentation du poids pendant les premières huit semaines et une élévation du taux de l'hémoglobine pendant les dernières vingt-quatre semaines dans le groupe traité. La mesure de l'épaisseur du pli cutané indiquait que dans le groupe traité par le méthénolone les dépôts graisseux sous l'épaule tendaient à augmenter et ceux à la partie dorsale du bras à diminuer. On n'a pas trouvé de différence significative en ce qui concerne l'image radiographique des mains, des pieds et de l'épine lombaire. Le seul effet secondaire particulier au groupe traité était l'acné (en 10 pour cent des cas).

\section{Investigación controlada del acetato de metenolona en enfermas con artritis reumatoide tratadas con prednisolona}

\section{SUMARIO}

Una investigación controlada, double-blind fué emprendida con el acetato de metenolona, $5 \mathrm{mg}$. dos veces al día por la vía oral en el tratamiento de enfermas con artritis reumatoide, y sometidas a la terapia prolongada con prednisolona; 58 enfermas completaron un año de esta investigación, 34 de ellas tomando la metenolona y las demás 24 sirviendo de testigos. Los dos grupos diferían poco entre sí respecto a la edad, estado menopáusico, peso, espesor del pliegue cutáneo, duración de la artritis reumatoide, duración de la terapia con prednisolona, velocidad de sedimentación eritrocitaria, cifras de hemoglobina, reacción de Waaler-Rose oco de fijación del latex, fuerza de la mano y capacidad funcional. No se encontró evidencia alguna de que las enfermas que dejaron de participar en el ensayo hubiesen podido afectar apreciadamente la comparabilidad de los grupos o los resultados finales.

Se encontraron sólo dos diferencias estadísticamente significativas entre estos grupos: un aumento de peso en las primeras ocho semanas y de la hemoglobina en las últimas 24 semanas-ambas en el grupo tratado. La medición del pliegue cutáneo indicó que en el grupo tratado por la metenolona los depósitos adiposos tendían a aumentar debajo de la espalda y a disminuir en la parte dorsal del brazo. No se encontró diferencia significativa en las alteraciones radiográficas de las manos, de los pies y de la columna lumbar. El único efecto secundario particular en el grupo tradado fué el acne (en un 10 por ciento de los casos). 